Vol. 9 (2000): 49-59.

\title{
Growth of and partitioning between shoot and storage root of carrot in a northern climate
}

\author{
Terhi Suojala \\ Agricultural Research Centre of Finland, Plant Production Research, Horticulture, Toivonlinnantie 518, \\ FIN-21500 Piikkiö, Finland, e-mail: terhi.suojala@mtt.fi
}

\begin{abstract}
Matching the growth pattern of a vegetable cultivar with the seasonal changes in climate is a prerequisite for successful yield production in a northern climate. This paper describes the growth characteristics of two carrot cultivars in relation to climatic conditions in two years, with special reference to the factors associated with high yield. Cv. Fontana produced twice as large a leaf area and shoot weight as cv. Panther. Increased partitioning to shoot in the former cultivar also resulted in a higher root yield. Uniformity in relative growth rates during the period of analysis suggests that intervarietal differences in the shoot to root ratio and in the yield potential appear very early. Nearly half of the root weight at final harvest was gained after mid-August, when temperature and daily irradiance began to decrease. A large leaf area may ensure better utilisation of diminishing growth resources at the end of the growing season. In the more favourable growing season, 1997, plants invested more in leaf production than they did in 1996: shoot fresh and dry weights were considerably higher but leaf area was not much higher.
\end{abstract}

Key words: carrots, cultivars, developmental stages, Daucus carota L., growth rate, yields

\section{Introduction}

The main factors determining the potential crop yield are leaf area, net assimilation rate, duration of growing period and utilisable fraction of the biomass (harvest index) (Forbes and Watson 1992). In a northern climate, the shortness of the growing season restricts the high yield that might be obtained through long duration of growth. A high yield can, however, be achieved by using cultivars which have a high net assimilation rate and which are able to maintain their growing potential even under the less favourable conditions prevailing at the end of the season. The harvest index should be optimal to ensure efficient partitioning to harvestable plant part while preserving a sufficient photosynthetic leaf area. In addition, leaf area development should match the seasonal variation in environmental condi- 


\section{AGRICULTURAL AND FOOD SCIENCE IN FINLAND}

\section{Suojala, T. Growth and partitioning in carrot}

tions to ensure the effective utilisation of growth resources.

Little information is available on the patterns of the vegetative development of carrot cultivars in a northern climate. Neither is the production physiology of carrot, e.g. effects of environmental factors on net photosynthesis, well understood. In contrast, the partitioning of photosynthates between shoot and storage root has been extensively studied. It is known that the distribution of dry matter between shoot and storage root is primarily determined by genotype, and that the genotypic differences arise very early (Stanhill 1977, Hole et al. 1983, Hole et al. 1987). Environmental factors such as light, temperature and density also influence shoot to root ratios, but the effect is often due to changes in plant size, since the shoot to root ratio generally decreases with plant age and size (Barnes 1979, Hole and Sutherland 1990).

This study aims to:

1 investigate the patterns of shoot and root growth of carrot in a northern climate

2 evaluate the characteristics that determine the potential of a cultivar to produce a high yield

3 investigate the yearly differences in the pattern of growth.

Two cultivars with contrasting growing habits were compared.

\section{Material and methods}

Material for growth analysis was obtained from a field experiment conducted at the Vegetable Experimental Site of the Agricultural Research Centre of Finland at Kokemäki $\left(61^{\circ} 16^{\prime} \mathrm{N}\right.$, $22^{\circ} 15^{\prime} \mathrm{E}$ ) in 1996 and 1997. The experiment comprised two cultivars arranged in a randomised complete block design with four replicates. The cultivars were Panther $F_{1}$ (Sluis and Groot, the Netherlands), which is a Nantes-type fresh-market variety commonly used for storage in Finland, and Fontana $F_{1}$ (Bejo Zaden, the Netherlands), which is a late Flakkee-type variety cultivated for the processing industry. The cultivars are known to have contrasting growing habits, cv. Panther producing small foliage and cv. Fontana large foliage.

A different experimental field was used in the two years to ensure proper crop rotation, but the distance between the fields was less than $100 \mathrm{~m}$ and the soil type remained similar, that is, fine sand rich in organic matter ( $\mathrm{pH}$ 6.0-6.3). Seeds were sown to a depth of $1 \mathrm{~cm}\left(114\right.$ seeds $\mathrm{m}^{-2}$, seedling emergence $87-89 \%$ of sown seeds) in double rows on a flat bed on 22 May in 1996 and on 14 May in 1997. The bed had four double rows $40 \mathrm{~cm}$ apart. The final density was approximately 40 plants per row metre in both cultivars and in both years. Fertiliser applied before sowing included $60 \mathrm{~kg} \mathrm{ha}^{-1}$ nitrogen, $42 \mathrm{~kg}$ ha $^{-1}$ phosphorus and $84 \mathrm{~kg} \mathrm{ha}^{-1}$ potassium (+other macronutrients and micronutrients in a compound fertiliser), and a top dressing with $20 \mathrm{~kg}$ $\mathrm{ha}^{-1}$ nitrogen was given in July. The field was irrigated three times in 1996 (altogether $60 \mathrm{~mm}$ ) and five times in 1997 (altogether $105 \mathrm{~mm}$ ). Chemical plant protection to control weeds and carrot psyllid (Trioza apicalis) was applied as necessary. Fungal diseases were not found.

Samples for growth analysis were taken at approximately 10-day intervals starting at 43 and 54 days after sowing in 1996 and 1997, respectively. The samples consisted of subsamples taken from each of six subplots reserved for six harvest dates used in the other part of the experiment (Suojala 1999). The subsamples of three plants were taken from two inner rows of each bed in a systematic order. At the first sampling, three adjacent plants were taken starting at $30 \mathrm{~cm}$ distance from the end of the plot; in the following samplings, a guard area including two carrot plants was left intact between the sampled plants. The results for the subsamples were averaged for the analysis of data; thus the variables analysed were based on 18 plants per replicate.

The samples were rinsed with water and analysed for the number of true leaves per plant (longer than $0.5 \mathrm{~cm}$ ), the length of the longest 
Vol. 9 (2000): 49-59.
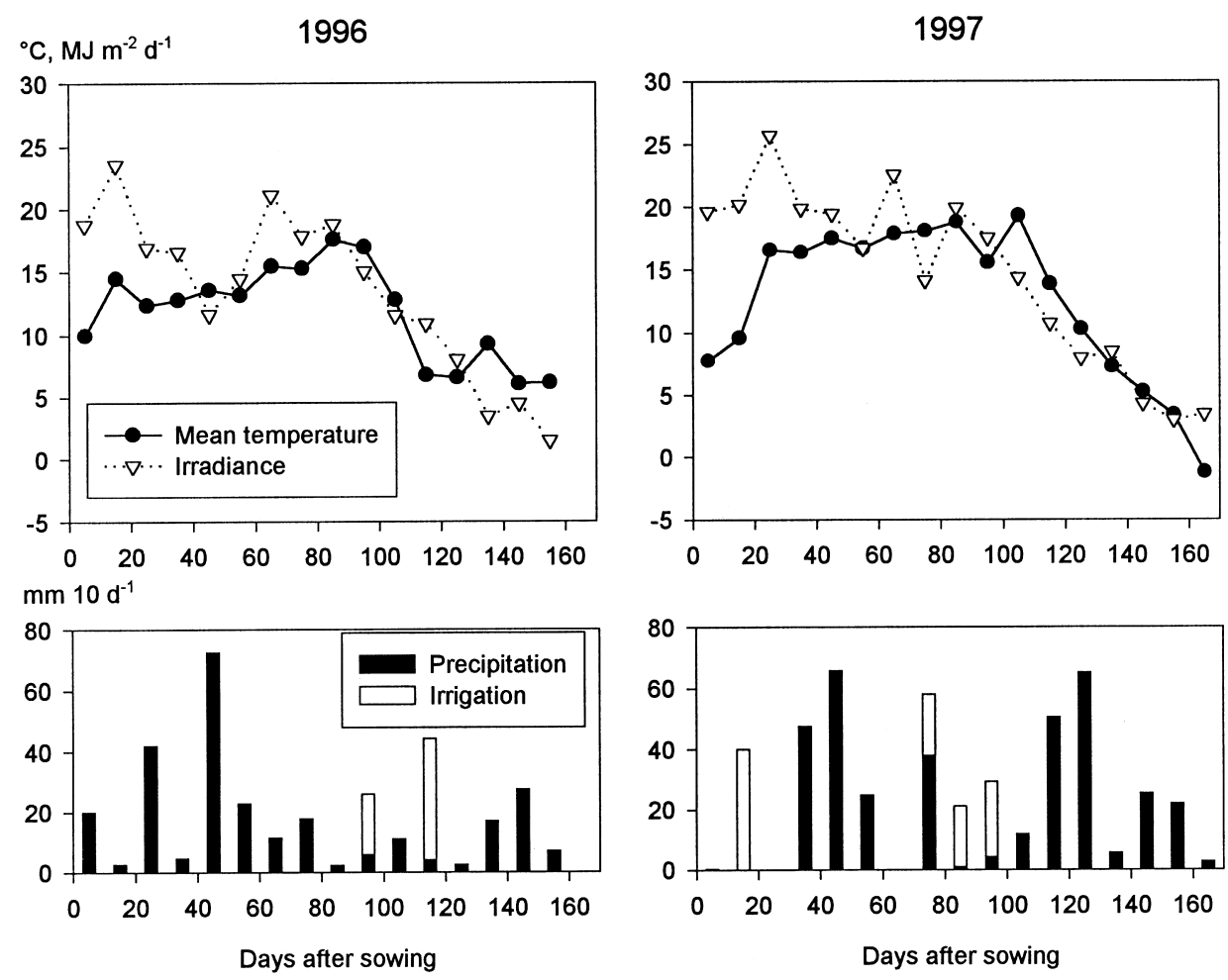

Fig. 1. Daily mean temperature and daily sums of global irradiance as the means of 10-day periods and precipitation and irrigation as 10-day sums.

leaf, fresh and dry weights of the leaves, the maximum thickness and length of the storage root and fresh and dry weights of the storage root. Dry weights were determined after the fresh sample had been dried to a constant weight at $70^{\circ} \mathrm{C}$. In addition, leaf area was measured on six plants per plot six times in 1996 and four times in 1997. Different methods of measurement were used in the two years: in 1996, leaf blades and petioles were photocopied onto a transparency, from which the leaf area was measured later by an LI3100 Area Meter (Li-COR Inc., Lincoln, Nebraska, USA). In 1997, the leaves were photocopied onto white paper and the leaf area was analysed by image analyses (Olympus Cue-2 Image Analyzer). Because of the different methods used, the results for the two years are not strictly com- parable. Specific leaf area (SLA) was calculated as the ratio of total leaf area per plant to total leaf dry weight per plant (Hunt 1990).

The mean relative growth rate (RGR) of total plant growth was calculated by the formula (Hunt 1990):

$\mathrm{RGR}=\ln \left(\mathrm{W}_{2}\right)-\ln \left(\mathrm{W}_{1}\right) /\left(\mathrm{t}_{2}-\mathrm{t}_{1}\right)$,

where $\mathrm{W}_{1}$ and $\mathrm{W}_{2}$ are total dry weights at successive times 1 and 2 and $t_{1}$ and $t_{2}$ are times as days after sowing.

\section{Weather data}

Data on daily mean temperatures and precipitation were obtained from the meteorological 
Suojala, T. Growth and partitioning in carrot

station of the Finnish Meteorological Institute situated at the Vegetable Experimental Site. The daily sum of global irradiance was measured at Jokioinen, $80 \mathrm{~km}$ from the Experimental Site. Figure 1 shows temperature and irradiance as means of 10-day periods and precipitation as 10-day sums. In 1996, the monthly mean temperatures were lower than the long-term average, except in August and October. In 1997, the monthly mean temperatures were high, only May being slightly colder and October considerably colder than the long-term average. Total precipitation from sowing date to the last harvest was $271 \mathrm{~mm}$ in 1996 and $365 \mathrm{~mm}$ in 1997.

\section{Statistical analysis}

Growth attributes were analysed by the following mixed model:

$\mathrm{y}_{\mathrm{ijk}}=\mu+\mathrm{B}_{\mathrm{i}}+\mathrm{C}_{\mathrm{j}}+\mathrm{BC}_{\mathrm{ij}}+\mathrm{T}_{\mathrm{k}}+\mathrm{BT}_{\mathrm{ik}}+\mathrm{CT}_{\mathrm{jk}}+\mathrm{e}_{\mathrm{ijk}}$;

where $\mu$ is the overall mean, $\mathrm{B}$ is the random effect of the block, $\mathrm{C}$ and $\mathrm{T}$ are the fixed effects of cultivar and time, respectively, BC, BT and $\mathrm{CT}$ are interactions and $\mathrm{e}_{\mathrm{ijk}}$ is the error term. The random variables $\mathrm{B}_{\mathrm{i}}, \mathrm{BC}_{\mathrm{ij}}, \mathrm{BT}_{\mathrm{ik}}$ and $\mathrm{e}_{\mathrm{ijk}}$ are all assumed to be independent and normally distributed with zero means and variances $\mathrm{s}_{\mathrm{B}}{ }^{2}, \mathrm{~s}_{\mathrm{BC}}{ }^{2} \mathrm{~s}_{\mathrm{BT}}{ }^{2}$ and $\mathrm{s}_{\mathrm{e}}^{2}$, respectively. Separate models were fitted for both years. The SAS MIXED procedure (Littell et al. 1996) was used to fit the mixed models by the restricted maximum likelihood (REML) estimation method.

Leaf and root weights and leaf area index were $\ln$-transformed prior to analysis to ensure homogeneity of variances. Checking the aptness of the models by residual analyses did not indicate any cross departures from the assumptions of the models.

Relationships between logarithmic storage root and shoot weights and between RGR and total plant weight were analysed by linear functional relationships using the SAS REG procedure (SAS Institute 1990).

\section{Results}

\section{Leaf growth}

Two cultivars showed marked differences in growth variables; leaf growth in particular varying markedly between the cultivars. The maximum shoot weight of cv. Fontana was about twice that of cv. Panther in both years (Fig. 2). Shoot fresh weights increased up to 90-100 days after sowing, remained at a plateau for up to 130 days after sowing and then decreased. Similarly, shoot dry weights reached their maxima at 100-130 days after sowing in both years. The number of leaves did not increase after 75-85 days after sowing, and the maximum length of leaves was reached at 96-106 days after sowing. The maximum fresh weight of the shoot was about $10 \mathrm{~g}$ higher and the dry weight $1 \mathrm{~g}$ higher in 1997 than in 1996 in both cultivars.

Leaf areas were measured only up to 95-115 days after sowing. Large differences in shoot weight were reflected in the leaf area index, which had a maximum measured value of 6 in cv. Fontana and about 3 in cv. Panther (Fig. 3). The absolute maximum values cannot be estimated, since leaf area could not be measured as regularly as other growth variables. The specific leaf area did not differ between the two cultivars, but it was lower in 1997 than in 1996. As a result, despite the higher shoot weight in 1997 , the leaf area was not much higher and thus the leaves were thicker. The higher leaf weight was not due to a larger number of leaves: on the contrary, plants produced one leaf less in 1997, but the leaves were longer (Fig. 2).

\section{Storage root growth}

Storage root weights increased up to the last harvests, with a slower growth rate at the end of the season (Fig. 4). Differences in the root weight between cultivars increased markedly at 100 days after sowing in both years. The higher root weight in 1997 was mainly due to the thickness 
1996

Leaf fresh weight $\left(\mathrm{g} \mathrm{plant}^{-1}\right)$

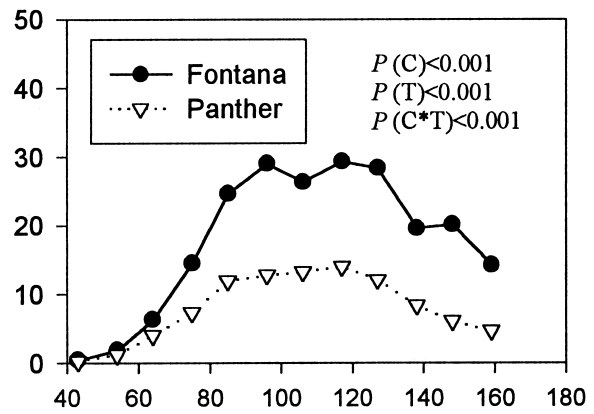

Leaf dry weight ( $\left.\mathrm{g} \mathrm{plant}^{-1}\right)$

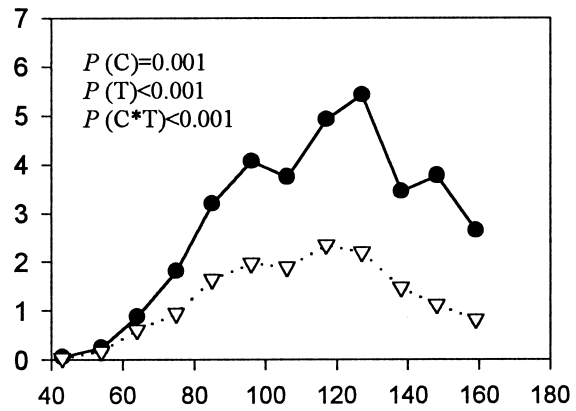

Number of leaves

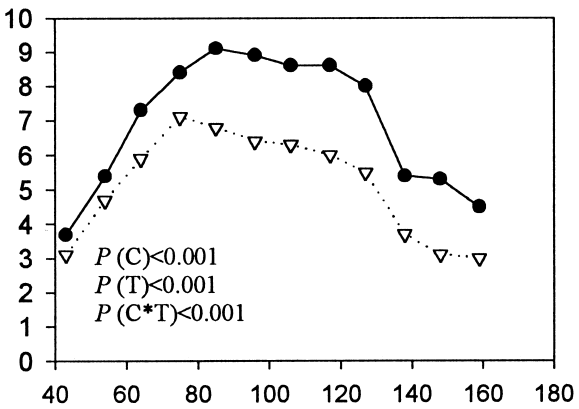

Maximum length of leaves $(\mathrm{cm})$

80
70

Fig. 2. Development 60 of weight, number 50 and length of leaves 40 during the growing season. Probability values are given for the effects of cultivar (C) and growing time (T) and for their interaction $\left(\mathrm{C}^{*} \mathrm{~T}\right)$.

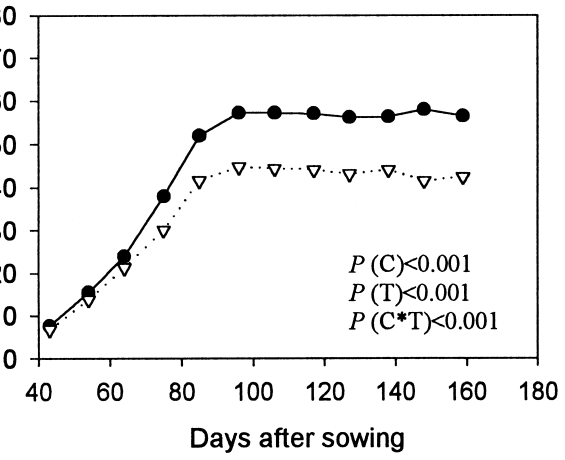

Leaf fresh weight $\left(\mathrm{g} \mathrm{plant}^{-1}\right)$
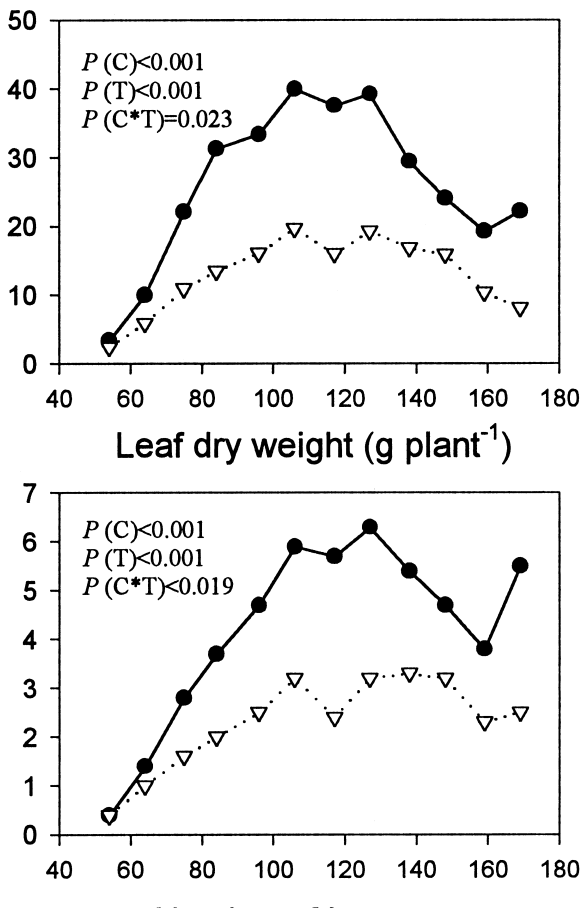

Number of leaves

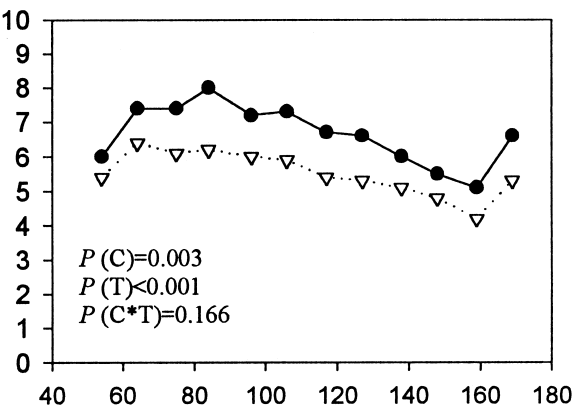

Maximum length of leaves $(\mathrm{cm})$

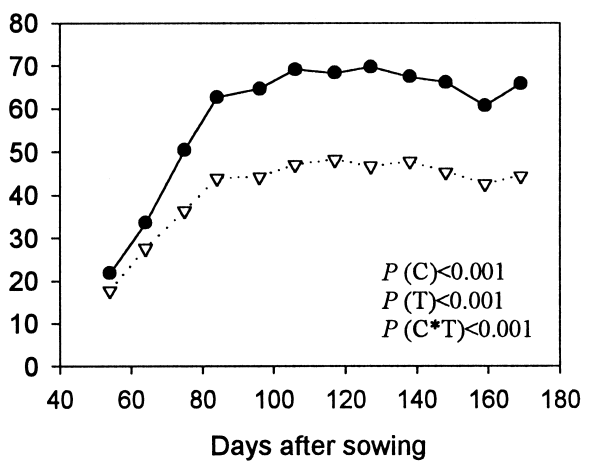


Suojala, T. Growth and partitioning in carrot

1996

Leaf area index

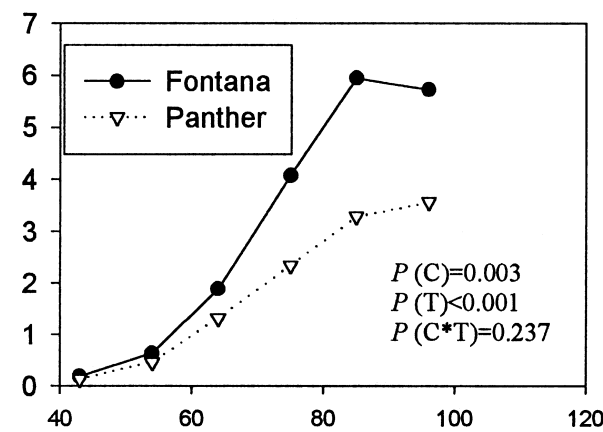

Specific leaf area $\left(\mathrm{cm}^{2} \mathrm{~g}^{-1} \mathrm{DW}\right)$

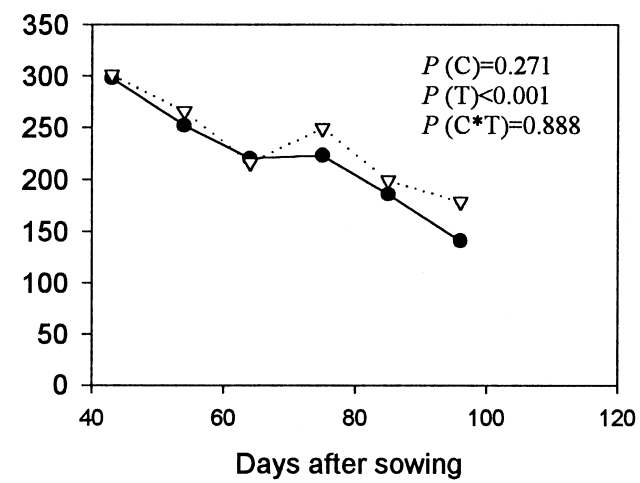

1997

Leaf area index

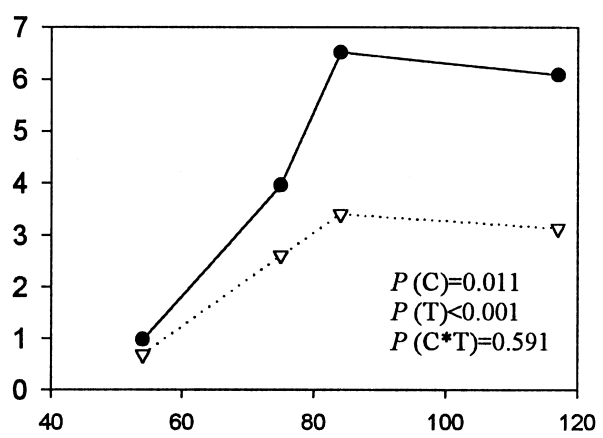

Specific leaf area $\left(\mathrm{cm}^{2} \mathrm{~g}^{-1} \mathrm{DW}\right)$

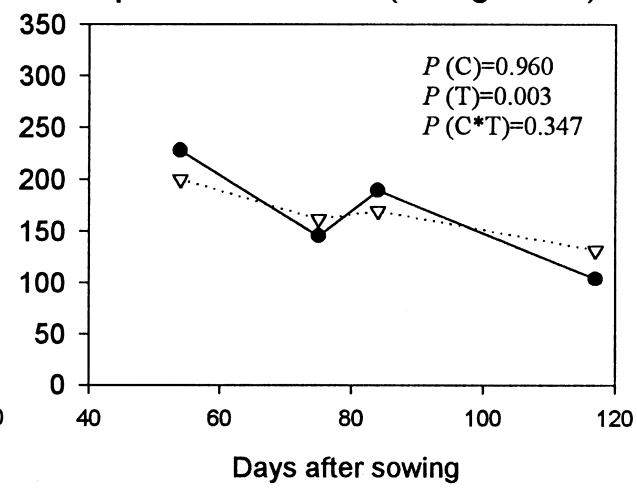

Fig. 3. Development of leaf area index and specific leaf area during the growing season. Probability values are given for the effects of cultivar $(\mathrm{C})$ and growing time $(\mathrm{T})$ and for their interaction $\left(\mathrm{C}^{*} \mathrm{~T}\right)$.

of the roots: only the roots of cv. Panther were slightly longer in 1997.

\section{Partitioning between shoot and storage root}

The relationship between logarithmic root and shoot weights was linear up to 106-127 days after sowing, after which leaf senescence lowered the ratio (Fig. 5). The linear phase was quantified by linear equations (Table 1). Cv. Fontana had a higher shoot to root ratio than cv. Panther, as indicated by the higher intercept and steeper slope. The slope values remained similar in the two years, but the intercepts were higher in 1997 , indicating higher partitioning to shoot during the early part of the growing season.

\section{Relative growth rate}

The relative growth rate diminished rapidly with time and a higher plant weight (Figs 6 and 7). RGR was similar in both cultivars in relation to growing time. At a given plant weight, RGR was lower in cv. Panther. 
Vol. 9 (2000): 49-59.

1996

1997

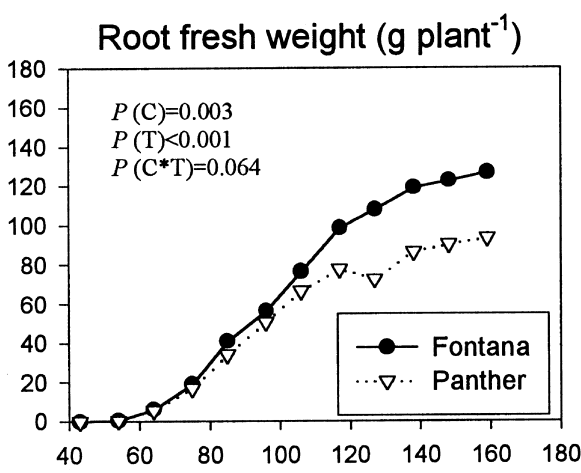

Root fresh weight (g plant $\left.{ }^{-1}\right)$

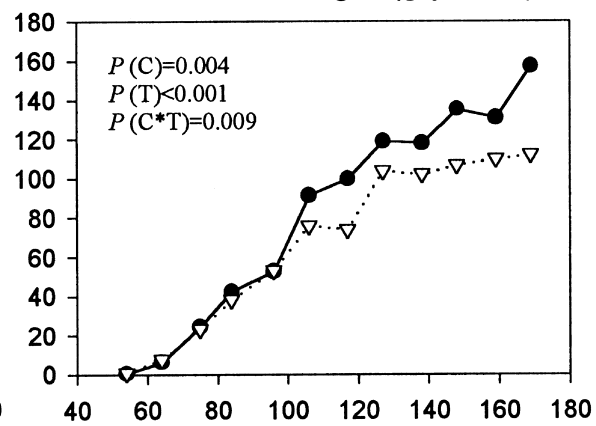

Root dry weight (g plant ${ }^{-1}$ )

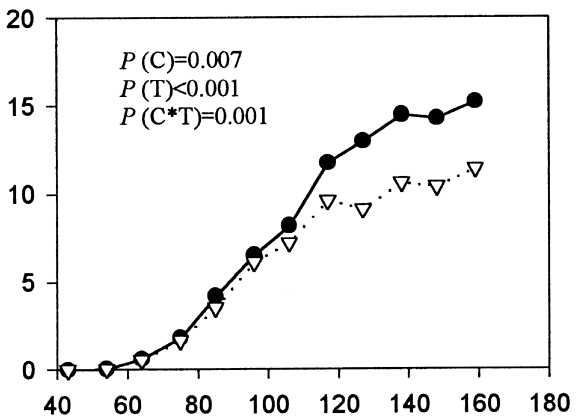

Root dry weight (g plant ${ }^{-1}$ )

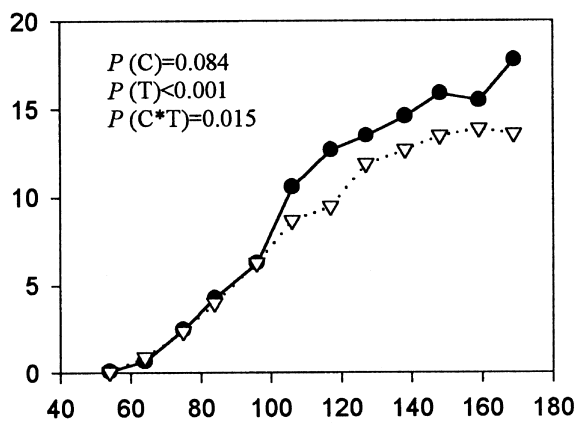

Root thickness (mm)
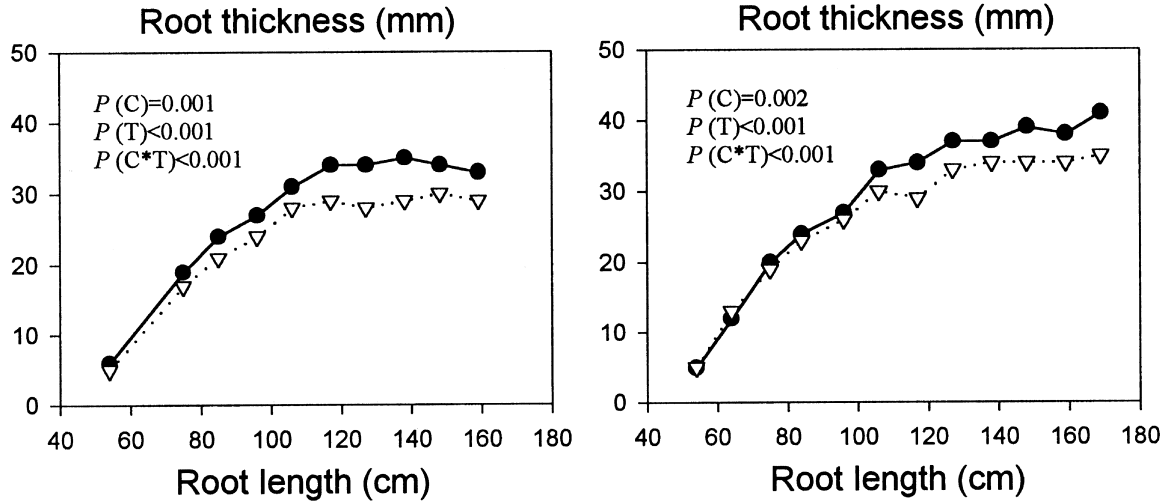

Fig. 4. Development of weight, thickness and length of storage roots during the growing season. Probability values are given for the effects of cultivar (C) and growing time $(\mathrm{T})$ and for their interaction $(\mathrm{C} * \mathrm{~T})$.
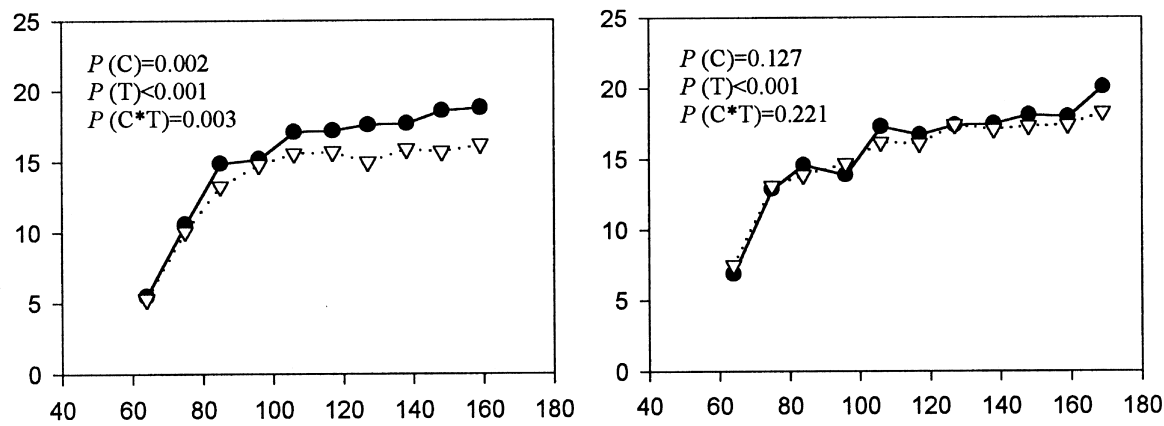

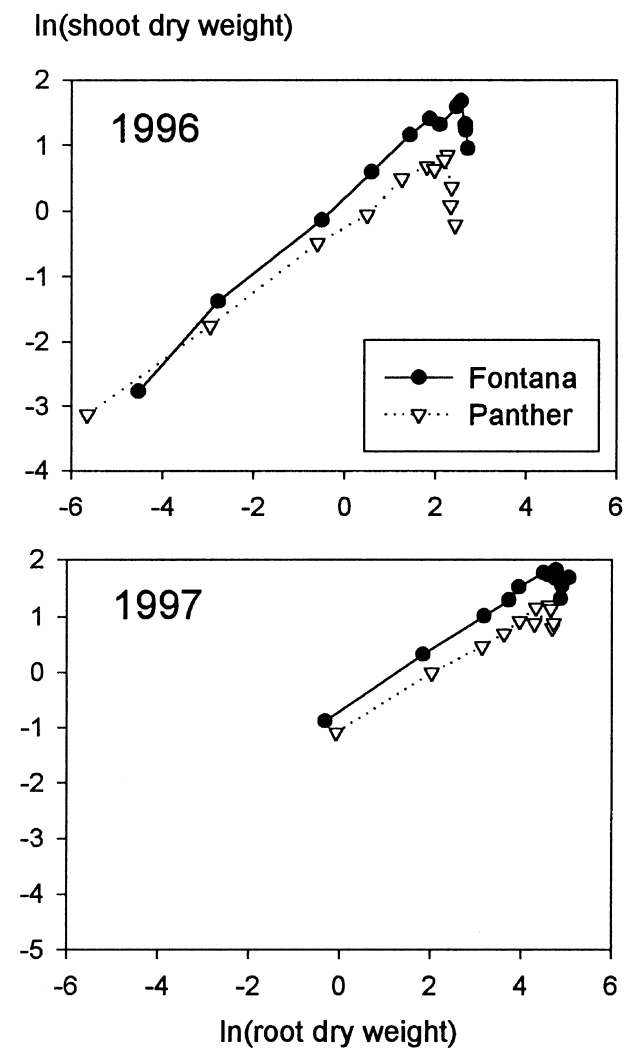

Fig. 5. Relation between logarithmic storage root weight and logarithmic shoot weight.

\section{Discussion}

\section{Patterns of growth}

In the experimental years, temperature and irradiance remained relatively high up to approxi- mately 100 days after sowing (Fig. 1). After this period, that is mid or late August, the daily sum of irradiance and mean temperature decreased clearly. By then, leaf area and leaf weight had reached their maximum. Root weight, however, doubled in $\mathrm{cv}$. Fontana and also increased in $\mathrm{cv}$. Panther after this point in time, hence in the less favourable climate. A decline in shoot weight at the end of the growing season due to senescence of the oldest leaves is a commonly known phenomenon, but its relation to root growth has varied. Our findings are in agreement with those of Fritz and Habben (1977), which showed that the shoot weight of different cultivars declined before maximum root weight was achieved. In a greenhouse, this occurred at 100 days after emergence and under field conditions 130-170 days after sowing. However, Nilsson (1987) reported that the cessation of root growth at the end of September in Sweden coincided with a fall in shoot weight, irrespective of sowing date. Wheeler et al. (1994) and Habben (1972) found no decline in shoot weight up to the last harvest at 4-5 months after sowing. Differences in leaf senescence may be cultivar-specific, but obviously maintenance of the photosynthetic potential, even at the end of the growing season, would ensure maximal root growth. In 1996, the low precipitation at the end of the season may have promoted dying of the oldest leaves.

\section{Cultivars}

Hole et al. (1987) reported that cultivars with a high root yield tend to have high shoot weights. The same was also seen in our study, in which

Table 1. Linear relations between logarithmic shoot $(s)$ and storage root $(r)$ dry weights $(\ln s=a+b * \ln r)$.

\begin{tabular}{lllrrrrrr}
\hline Year & Cultivar & $\begin{array}{l}\text { Period, } \\
\text { days after sowing }\end{array}$ & a & $(95 \% \mathrm{CI})$ & $\mathrm{b}$ & $(95 \% \mathrm{CI})$ & $\mathrm{r}^{2}$ \\
\hline \multirow{2}{*}{1996} & Fontana & $43-127$ & 0.168 & $(0.104,0.232)$ & 0.608 & $(0.582,0.635)$ & 0.98 \\
& Panther & $43-127$ & -0.257 & $(-0.295,-0.219)$ & 0.497 & $(0.481,0.512)$ & 0.99 \\
& Fontana & $54-106$ & 0.515 & $(0.429$, & $0.601)$ & 0.545 & $(0.494,0.596)$ & 0.96 \\
& Panther & $54-106$ & 0.022 & $(-0.010,0.054)$ & 0.515 & $(0.494,0.534)$ & 0.99 \\
\hline
\end{tabular}


Vol. 9 (2000): 49-59.

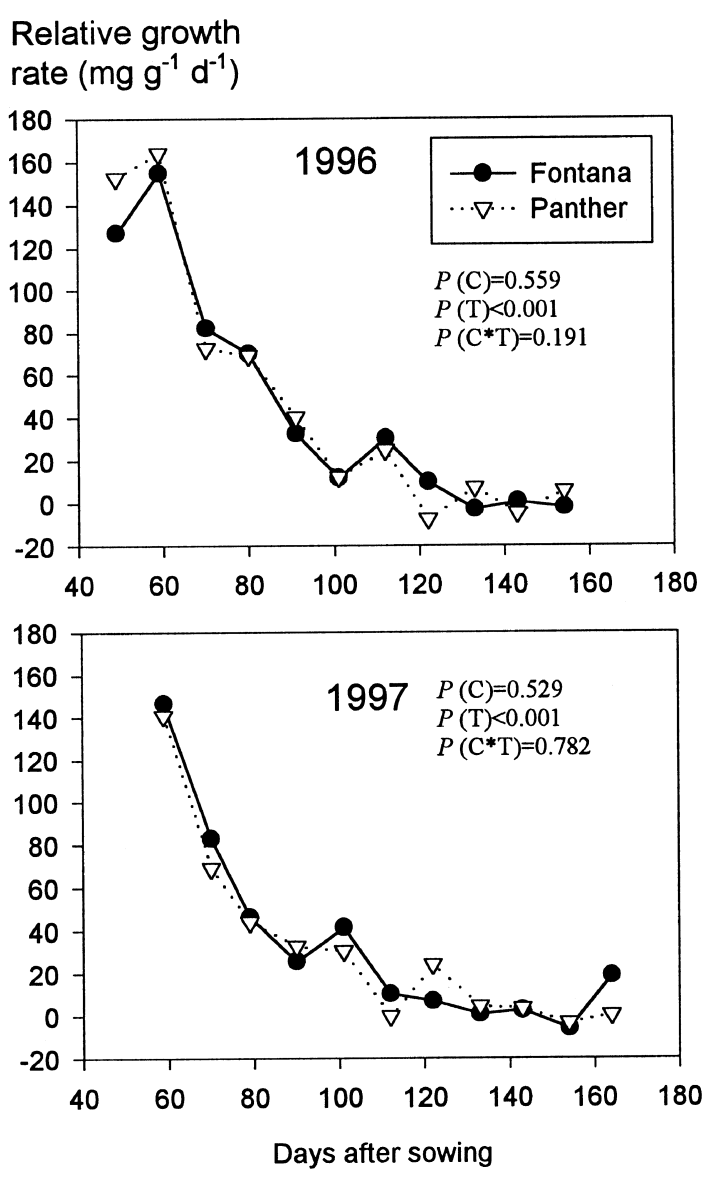

Fig. 6. Relative growth rate of total plant weight during the growing season. Probability values are given for the effects of cultivar $(\mathrm{C})$ and growing time $(\mathrm{T})$ and for their interaction $(\mathrm{C} * \mathrm{~T})$.

cv. Fontana, with a high shoot weight and large leaf area, also produced a higher root yield. Surprisingly, the commonly used concept "earliness" did not bear any relation to intensity of growth: cv. Fontana, considered a late variety under our conditions, had higher shoot and root weights throughout the period analysed. However, the relative growth rates were similar in both cultivars in relation to time from sowing, which shows that the differences had arisen earlier. No clear differences in the emergence rate of the cultivars were noted. Therefore, the higher potential for yield formation in cv. Fontana

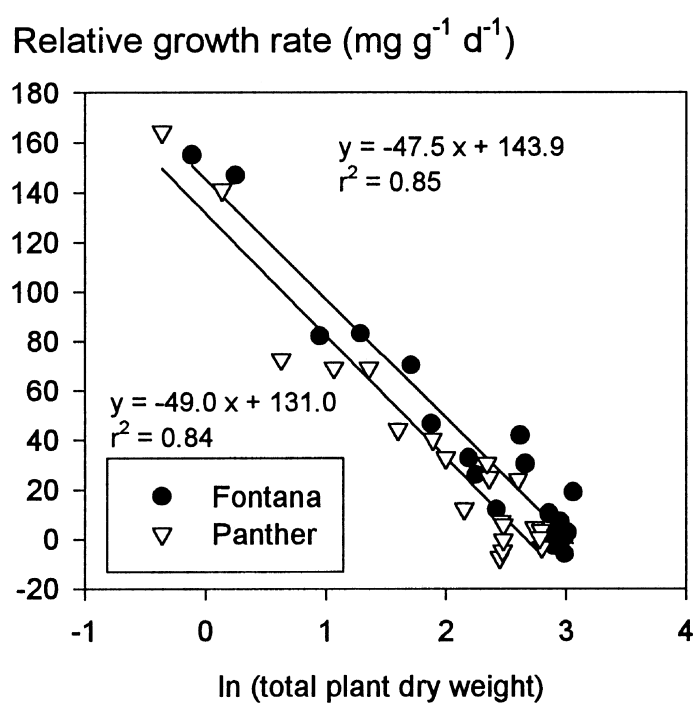

Fig. 7. Relative growth rate in relation to total plant weight.

seems to be determined soon after emergence, probably due to the stronger partitioning to shoot growth. It would seem that partitioning to leaf production at an early stage, resulting in a higher shoot to root ratio, ensures a potential for high biomass production and high root weight (Hole et al. 1987). Hole et al. (1987) concluded that the shoot to root ratio characteristic of a given cultivar was determined within 27-48 days of sowing. The determining factor in the shoot to root ratio may be the relative growth rates of shoot and root at an early stage (Hole et al. 1987). It is also suggested that fibrous root activity during initiation of the storage root may contribute to regulation of the shoot to root ratio (Hole and Dearman 1990).

Although the relative growth rates of the two cultivars were similar at a given time, they were higher in cv. Fontana at a given plant weight. The most likely explanation is that cv. Panther reached the same plant weight as cv. Fontana later in the growing season and therefore under less favourable growing conditions. The differences in root weight between cultivars increased markedly after late August, which suggests that the smaller leaf area of cv. Panther was not sufficient for the full utilisation of the diminishing 
Suojala, T. Growth and partitioning in carrot

growth resources. The decrease in growth rate in larger plants is probably due to the competition between plants and limiting growth resources. Therefore, the effect of plant weight on relative growth rate is likely to be dependent on the environmental conditions and does not necessarily indicate a causal relation.

The relationship between logarithmic shoot and root dry weights showed cultivar-specific values, cv. Fontana having a higher partitioning to shoot than cv. Panther, as indicated by the higher intercept and slightly steeper slope in the linear regression. Hole et al. (1983) showed that carrot cultivars differed only in the values of the intercept $\alpha$, which increased with the later maturity of a cultivar. This was also confirmed in our study, while the slope was also steeper for cv. Fontana, especially in 1996 . The relation between root and shoot weights was linear during most of the growing season, but leaf senescence resulted in a decline in the ratio. This is in contrast to the model developed by Barnes (1979), in which the intercept changed linearly with time, and a time-dependent parameter was included in the model. The time-dependence was due to maintenance respiration of the shoot and root tissues. Leaf senescence, which clearly broke down the linear dependency in our data, was not considered significant in the model of Barnes (1979).

\section{Years}

Comparison of the years showed that in 1997, the year with higher temperature and global radiation, plants invested more in leaf production by growing a lower number of thicker and longer leaves. The stronger partitioning to shoot was also seen in the linear equations between shoot and root weights, the intercepts being higher in 1997. This finding supports the suggestion that high temperature is more favourable for shoot growth than for storage root growth (Hole 1996). Leaf area was not much higher, which resulted in a lower specific leaf area in 1997. A similar finding was made by Hole and Dearman (1993), who showed that, at low photosynthetic photon flux density, carrot maintains its leaf area and leaf fresh weight, whereas the dry weight of leaves is diminished. Storage root growth is therefore limited less in carrot than in other species. The maintenance of leaf area under less favourable conditions was also seen in our results in 1996, but the leaf fresh and dry weights were reduced in that year.

In conclusion, the basic factors associated with high root yield are a large leaf area and high shoot weight developing early in the growing season. Even though cv. Fontana had a higher shoot to root ratio, and thus a smaller harvest index, it was able to produce not only a higher biomass but also a higher root weight. This is suggested to result partly from better utilisation of the diminishing growth resources. Since a considerable part of the growing time of late harvested field vegetables coincides with less favourable growing conditions, greater effort should be made to produce a large photosynthetic capacity early enough, for instance by optimising sowing time, by promoting emergence (seed priming, preparation of the seed bed, covering with moulches) or by using cultivars with fast early growth. The results reported here are for two cultivars only. Research should therefore be extended to the determination of root yield in other cultivars and the regulation of early development.

\section{References}

Barnes, A. 1979. Vegetable plant part relationships. II. A quantitative hypothesis for shoot/storage root development. Annals of Botany 43: 487-499.

Forbes, J.C. \& Watson, R.D. 1992. Plants in agriculture.
Cambridge: University Press. 355 p.

Fritz, D. \& Habben, J. 1977. Einfluß des Erntezeitpunktes auf die Qualität verschiedener Möhrensorten. Gartenbauwissenschaft 42: 185-190. 
Vol. 9 (2000): 49-59.

Habben, J. 1972. Einfluß einiger Standortfaktoren auf Ertrag und Qualität der Möhre (Daucus carota L.). Gartenbauwissenschaft 37: 345-359.

Hole, C.C. 1996. Carrots. In: Zamski, E. \& Schaffer, A.A. (eds.). Photoassimilate distribution in plants and crops. New York: Marcel Dekker. p. 671-690.

-, Barnes, A., Thomas, T.H., Scott, P.A. \& Rankin, W.E.F. 1983. Dry matter distribution between the shoot and storage root of carrot (Daucus carota L.). I. Comparison of varieties. Annals of Botany 51: 175187.

- \& Dearman, J. 1990. Partition of ${ }^{14} \mathrm{C}$ assimilate between organs and fractions of contrasting varieties of carrot during initiation of the storage root. Journal of Experimental Botany 41: 557-564.

- \& Dearman, J. 1993. The effect of photon flux density on distribution of assimilate between shoot and storage root of carrot, red beet and radish. Scientia Horticulturae 55: 213-225.

-, Morris, G.E.L. \& Cowper, A.S. 1987. Distribution of dry matter between shoot and storage root of fieldgrown carrots. I. Onset of differences between cultivars. Journal of Horticultural Science 62: 335-341.

- \& Sutherland, R.A. 1990. The effect of photon flux density and duration of the photosynthetic period on growth and dry matter distribution in carrot. Annals of Botany 65: 63-69.

Hunt, R. 1990. Basic growth analysis. London: Unwin Hyman, $112 \mathrm{p}$.

Littell, R.C., Milliken, G.A., Stroup, W.W. \& Wolfinger, R.D. 1996. SAS ${ }^{\circledR}$ System for Mixed Models. Cary, NC: SAS Institute Inc. 633 p.

Nilsson, T. 1987. Growth and chemical composition of carrots as influenced by the time of sowing and harvest. Journal of Agricultural Science 108: 459-468.

SAS Institute Inc. 1990. SAS/STAT User's guide, Version 6, 4th ed. Vol. 2. Cary, NC: SAS Institute Inc. $1686 \mathrm{p}$.

Stanhill, G. 1977. Allometric growth studies of the carrot crop. I. Effects of plant development and cultivar. Annals of Botany 41: 533-540.

Suojala, T. 1999. Cessation of storage root growth of carrot in autumn. Journal of Horticultural Science \& Biotechnology 74: 475-483.

Wheeler, T.R., Morison, J.I.L., Ellis, R.H. \& Hadley, P. 1994. The effects of $\mathrm{CO}_{2}$, temperature and their interaction on the growth and yield of carrot (Daucus carota L.). Plant, Cell and Environment 17: 12751284.

\title{
SELOSTUS
}

\section{Porkkanan kasvu ja biomassan jakautuminen varastojuuren ja verson välillä pohjoisissa oloissa}

\author{
Terhi Suojala \\ Maatalouden tutkimuskeskus
}

\begin{abstract}
Vihanneslajikkeiden kasvurytmin oikea ajoittuminen suhteessa ympäristötekijöiden muutoksiin on sadontuotannon edellytys pohjoisissa oloissa. Tässä tutkimuksessa kuvataan kahden porkkanalajikkeen kasvua suhteessa säätekijöihin kahtena koevuonna, erityistavoitteena arvioida satopotentiaalia sääteleviä kasvumuuttujia. Fontana-lajike tuotti kaksinkertaisen lehtialan ja lehtimassan Panther-lajikkeeseen verrattuna. Suurempi lehtimassa ja -ala edesauttoivat myös suuren juurisadon muodostumista. Molempien lajikkeiden suhteellisten kasvunopeuksien yhtäsuuruus kasvukaudella merkitsee, että lajikkeiden väliset erot
\end{abstract}

verso/juuri -suhteessa ja satopotentiaalissa syntyvät hyvin aikaisin. Lähes puolet varastojuurten painosta syntyi elokuun puolivälin jälkeen, jolloin lämpötila ja säteily alkoivat selvästi vähetä. Suuri lehtiala varmistanee vähenevien kasvutekijöiden tehokkaamman hyväksikäytön kasvukauden lopulla. Sääoloiltaan suotuisampana kasvukautena 1997 kasvit sijoittivat yhteyttämistuotteitaan enemmän lehtien tuotantoon kuin vuonna 1996: lehtien tuore- ja kuivapainot olivat selvästi korkeammat, mutta lehtiala ei paljon vaihdellut eri vuosina. 